\title{
Studies on Bacterial Kidney Disease in Atlantic Salmon (Salmon salar) in Canada
}

\author{
W. D. Paterson*, S. P. Lall and D. Desautels \\ Dept. of Fisheries and Oceans, Fisheries and Environmental Sciences Division, \\ Halifax Laboratory, Halifax, N. S. Canada. B3J 2S7
}

\begin{abstract}
The widespread nature of Renibacterium salmoninarum, the causative agent of bacterial kidney disease (BKD) among salmonid fish, was demonstrated in trout and salmon samples taken over the past 20 years from freshwater streams and salt water sites located on Cape Breton Island, Nova Scotia, Canada. Although ubiquitous in this area, major mortalities have been reported from only a few isolated locations. However, heavy losses do occur when infected fish are acclimated to sea water prior to their salt water phase of life. The diagnosis of bacterial kidney disease, which once depended on the Gram stain of a kidney smear, now utilizes more sensitive, serological confirmation techniques such as the fluorescent antibody technique or precipitin test.

In Atlantic salmon smolts, this disease exists in many internal organs but bacterial numbers concentrate in the kidney and proliferate as the temperature surpasses $4^{\circ} \mathrm{C}$ in the Spring. In advanced infections, lesions or bacterial pustules form on several organs but most often on the kidney.

We have investigated vaccination and nutrition as possible prophylactic methods to minimize BKD infection occurrence and severity. In vaccination trials, post yearling Atlantic salmon parr administered a $0.1 \mathrm{~m} l$ intraperitoneal injection of formalin killed BKD cells emulsified in Freund's complete adjuvant showed an elevated agglutinating antibody response and almost complete absence of BKD lesion formation in the kidneys. In the nutritional studies, a reduction in the incidence of BKD infections with lesions was observed in the July sample among fish fed diets with a high concentration of trace elements or a low calcium content. This therapeutic effect was attributed to the increased availability of trace elements for metabolic purposes.
\end{abstract}

Bacterial kidney disease (BKD) infections occurring among salmonid fish in many areas of Canada are caused by a fastidious Gram positive diplobacillus (BELL, 1961; PIPPY, 1969; EVELYN et al., 1973; YамAMOTO, 1975; PATERSON et al., 1979) recently named Renibacterium salmoninarum (Sanders and Fryer, 1980).

At the Canadian Government Fish Culture Station on the Margaree River, Cape Breton, Nova Scotia; overt, or symptomatic BKD infections occur annually among Atlantic salmon (Salmo salar) during smoltification (PIPPY, 1969; FRANTSI et al., 1975). These populations, exhibiting a high incidence of gross BKD infections (organ lesions), suffer heavy mortality during final hatchery holding and on release into sea water (FRANTSI et al., 1975). FRANTSI et al. (1977) using adult return data and minimal disease diagnosis, reported on the possible negative effects of BKD on salmon returns.
Further work is necessary in this important aspect of BKD.

This report on Renibacterium salmoninarum caused bacterial kidney disease in Atlantic salmon discusses several pertinent aspects of the disease including detection methods, internal organs affected, distribution among wild salmonids in Cape Breton, and possible prophylactic measures investigated in Halifax to control the disease.

\section{Detection}

Since the fastidious nature of the Renibacterium salmoninarum causative agent did not lend itself to diagnosis by culture isolation from fish until recently, other procedures have been routinely used to detect this disease. Historically, a presumptive positive diagnosis was indicated by the presence of small Gram positive rods either in the blebs in the

* Present Address: Connaught Laboratories Limited, 1755 Steeles Avenue West, Willowdale, Ontario. M2N 5T8 
pustules found on internal organs or on organs without the presence of overt pathology (BELDING and Merril, 1935; EarP et al., 1953; SMith, 1964).

Recently introduced serological techniques have increased the diagnostic sensitivity while providing a serological confirmation of BKD infections (Bullock and Stuckey, 1975, Chen et al., 1974; Kimura et al., 1978; Kimura, 1978; Bullock et al., 1980). The antigenic homogeneity and uniqueness of the Renibacterium salmoninarum isolates found in salmonid fish infections here, adds confidence to our use of serology for identification of this causative agent.

Cultivation of the BKD agent from asymptomatic or covert infections can now be facilitated using $\mathrm{KDM}_{2}$ media developed by EVELYN (1977). This consititutes a substantial improvement over the original cultivation techniques which required heavy, usually overt infections before cultures were obtained (ORDAL and EARP, 1956).

An assessment of BKD detection procedures (PAterson et al., 1979) revealed that IFAT gave an incidence of BKD twice that demonstrated by other techniques (Table 1). Isolation and culture of the causative agent on the supplemented Mueller Hinton Medium proved to be less sensitive than IFAT, but more sensitive than the generally practiced diagnosis by Gram stain. Other investigators have demonstrated similar improved sensitivity using serological procedures (CHEN et al., 1974; Bullock and Stuckey, 1975; Kimura, 1978; LAIDLER, 1980; Bullock et al. 1980).

Although the kidney is one of the main organs infected and affected by Renibacterium salmoninarum, pathology has also been demonstrated in the spleen, heart, liver, stomach and intestine. (EARP et al. 1953; WOOD and YASUTAKE, 1956; KaWAMURa et al., 1978).
In Nova Scotia, we have examined various organs from two year old smoltifying Atlantic salmon using the Indirect Fluorescent Antibody Technique (IFAT) (Bullock and Stuckey 1975). Samples were monitored in February $\left(\mathrm{Temp} 1{ }^{\circ} \mathrm{C}\right)$ in April and May (Temp 2-4 ${ }^{\circ} \mathrm{C}$ ) and in June when higher temperatures existed (Temp $8-10^{\circ} \mathrm{C}$ ). The data from 30 individual fish at each period was recorded to indicate presence of the disease $(\%$ of animals infected) and severity of infection (Mean $\#$ of fluorescing bacteria/50 microscope fields).

The severity of BKD infections as expressed by presence of organ lesions increases at the higher temperatures $\left(8-10^{\circ} \mathrm{C}\right)$ of the June sampling period (Fig. 1). The causative agent of BKD was present in all organs and tissues monitored including blood, feces, kidney, liver, spleen, stomach, heart and intestine (Fig. 2) at every sampling period. The kidney was the main organ infected and affected by Renibacterium salmoninarum (Fig. 3). Both the number of bacteria present in kidney smears

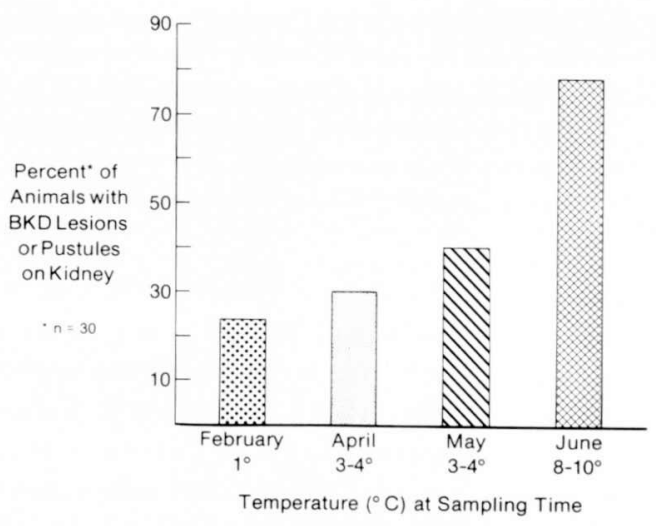

Fig. 1. Detection of bacterial kidney disease lesions or pustules on the kidney of Atlantic salmon (Salmo salar) at several sampling periods. Sample size $/$ period $=30$ fish.

Table 1. Comparison of methods used to diagnose bacterial kidney disease

\begin{tabular}{cccccc}
\hline & $\begin{array}{c}\text { Presence of } \\
\text { lesions }\end{array}$ & $\begin{array}{c}\text { Presence of } \\
\text { Gram-positive } \\
\text { rods in } \\
\text { kidney smears }\end{array}$ & $\begin{array}{c}\text { Presence of } \\
\text { small } \\
\text { nonmotile } \\
\text { rods in kidney }\end{array}$ & $\begin{array}{c}\text { Presence of } \\
\text { fluorescing } \\
\text { bacteria } \\
\text { (Psing IFAT) } \\
\text { mount) }\end{array}$ & $\begin{array}{c}\text { Culture of } \\
\text { BKD organism }\end{array}$ \\
\hline $\begin{array}{c}\text { Positive for BKD } \\
\% \text { Incidence of BKD }\end{array}$ & $22 / 50$ & $17 / 47$ & $22 / 50$ & $47 / 50$ & $29 / 50$ \\
58 & 36 & 44 & 94 & 58 \\
\hline
\end{tabular}

a A heavily infected population of live 2-yr-old smolting Atlantic salmon was used. 


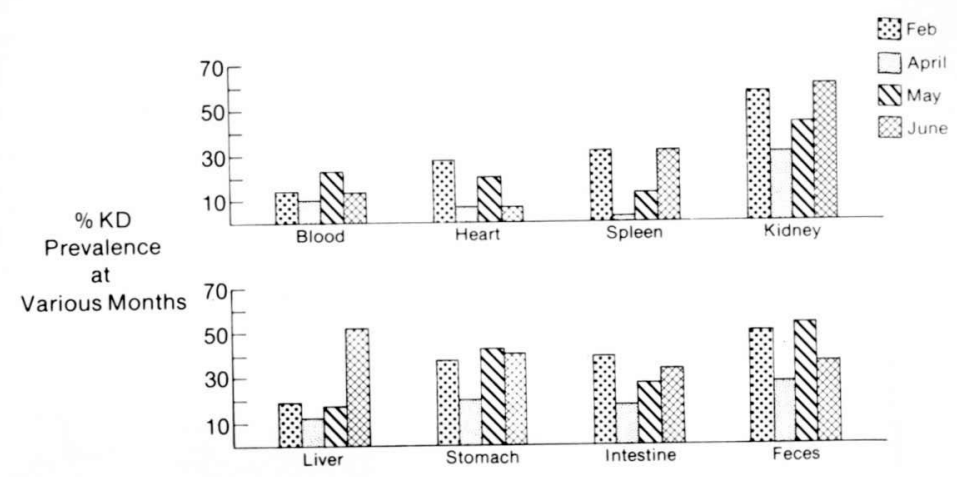

Fig. 2. Incidence of bacterial kidney disease in samples taken from various organs of Atlantic salmon smolts at several sampling periods. Sample size/period $=30 \mathrm{fish}$. Detection by indirect fluorescent antibody technique.

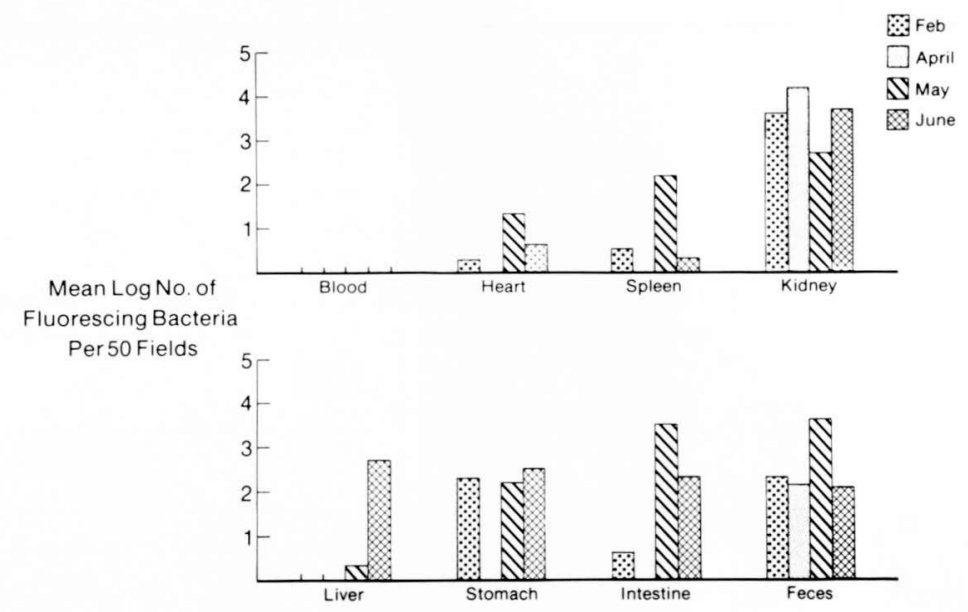

Fig. 3. Relative density of Renibacterium salmoninarum bacteria detected in various Atlantic salmon organs at several sampling periods using the indirect fluorescent antibody technique. Sample size $/$ period $=30$ fish.

Fig. 3) and the percent of animals with KD positive bacteria (Fig. 2) were highest in the kidney. Although pustules or lesions occurred on organs other than kidneys, the presence of this pathology was most frequent on the kidney.

\section{Distribution in Cape Breton, Nova Scotia, Canada}

In an effort to determine the distribution of BKD in this area, the Indirect Fluorescent Antibody Technique (IFAT) was used to monitor wild salmonids of the Margaree River, its tribu- taries and some adjacent rivers for the presence of this disease.

Wild Atlantic salmon parr and brook trout (Salvelinus fontinalis) were electroseined in the summer of 1977 from various waterways in Cape Breton. Samples of returning adult Atlantic salmon trapped commercially off the Cape Breton Island (Nova Scotia) coast and angled in the Margaree sport fishery were monitored for BKD. We also examined formalin-preserved Atlantic salmon parr electroseined from various Margaree Valley waters by Dr. P. ELSON in 1957 and 196568. Kidney smears from each fish were made on 
acetonecleaned glass slides which were then stained according to the IFAT of BULLOCK and STUCKEY (1975).

The examination of formalin-preserved samples showed that BKD has been present in Cape Breton Island for at least 20 years (Fig. 4). Every tributary of the Margaree system except for the Calumruadh Brook proper, contained KD-infected trout and/or salmon. In addition, BKD was detected in many adjacent rivers including the Cheticamp River, Mabou River, Judique Interval Brook, Baddeck River system, and the Middle River system, all locations where there had been no previous history of BKD.

Although none of the fish examined had overt or symptomatic BKD infections, the kidneys of two
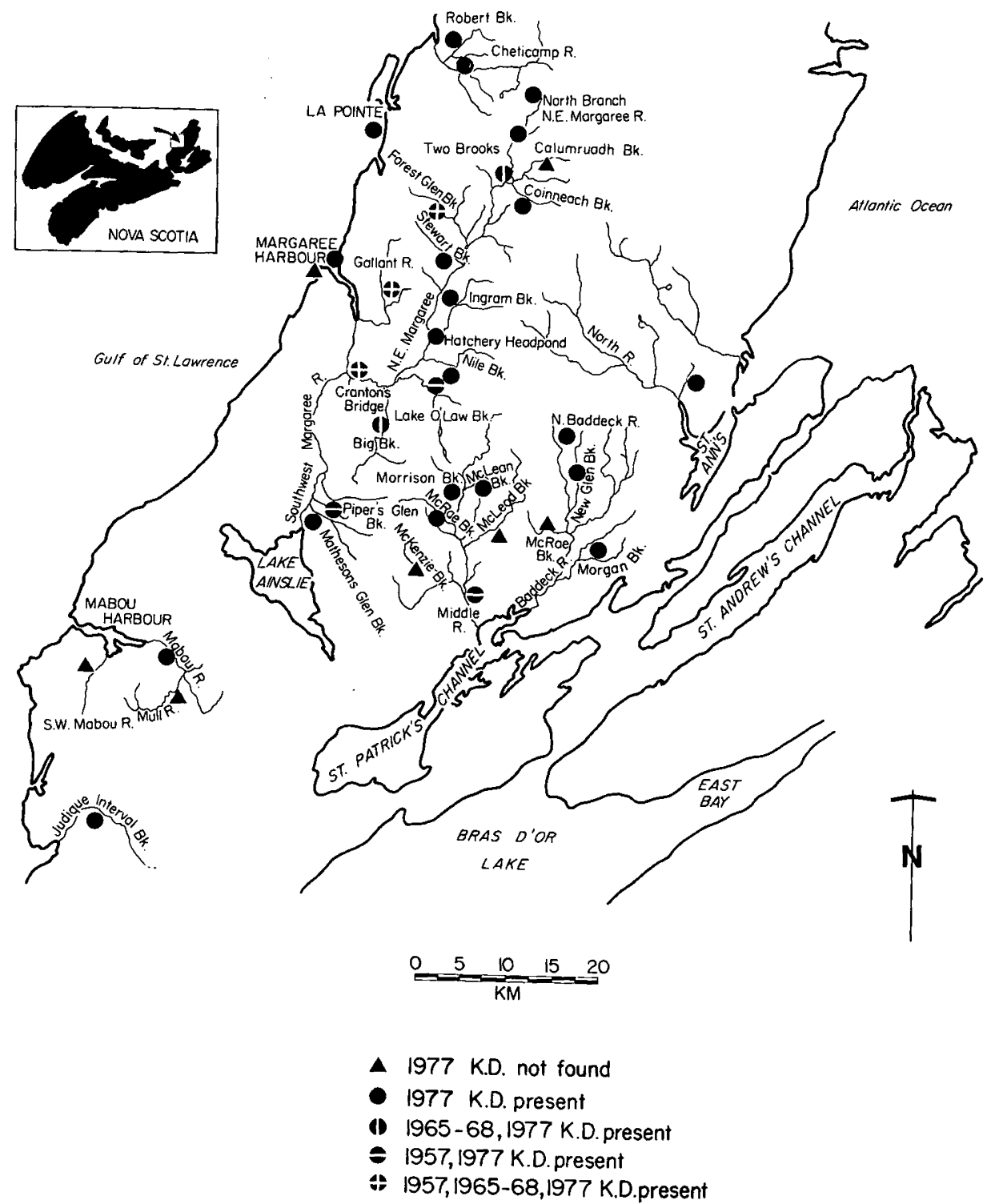

Fig. 4. Detection of bacterial kidney disease in the Margaree River, its tributaries and some adjacent rivers, using an indirect fluorescent antibody procedure. 
salmon parr caught near the source of the Margaree River (on the North Branch of the Northeast Margaree River) were shown by IFAT to be heavily infected with BKD bacteria ( 200 bacteria per $788 \times$ microscope field). This suggests that chronic advanced infections, severe enough to cause death, may occur in nature.

The data in this report indicate that a pool of BKD infection exists in nature at a high level among juvenile salmonids and raises the question of transmission routes and virulence in the wild. The demonstration of kidney disease in wild Margaree system Atlantic salmon parr sampled in 1957, 1965-68, and 1977, indicates the enzootic nature of this disease in this area of Cape Breton during at least the last 20 years. There have been other reports of $\mathrm{KD}$ infections in wild immature salmon, (PIPPY, 1969 and Frantsi et al., 1975) but the widespread nature of covert infection among wild salmonid stocks was not observed. Kidney disease monitor programs in progress in other areas of Canada indicate that Renibacterium salmoninarum may be ubiquitous elsewhere. An interesting observation of this survey and others, indicates that the mere presence of the pathogen as detected by IFAT is not necessarily indicative of a lesion producing disease state among a fish population, but poses the potential for one.

Bacterial kidney disease infections have also been observed among returning adult Pacific and Atlantic salmon. In the present work using IFAT diagnosis, $37.5 \%$ of examined adult Atlantic salmon returning up the Margaree River were covertly infected with $\mathrm{KD}$ and $33 \%$ of a group of adults trapped in saltwater at $\mathrm{La}$ Pointe also had covert KD infections. Detection of KD in salmon taken commercially in saltwater traps near La Pointe suggests that these animals had contracted KD infection sometime during their life cycle prior to ascent of freshwater streams. Overt KD infections also occur in wild salmon in salt water. ELLIS et al. (1978), reported the isolation of the causative agent of $\mathrm{KD}$ from lesions on the kidney and heart of an immature chinook salmon found in seawater; the first record of a KD infected fish found at sea.

The presence of steady populations of Atlantic salmon parr over a 20 -year period during which $\mathrm{KD}$ had been enzootic in the area, indicates that these fish survive the presence of the disease. A similar investigation for other stages of salmon such as smolt and adult is needed before we can accurately evaluate the effect of KD on wild fish populations and the significance of covert infections.

\section{Prophylaxis}

In order to minimize the effects of bacterial kidney disease we have investigated the value of vaccination, nutrition therapy, and chemotherapy. This section describes the results of experiments to vaccinate yearling Atlantic salmon by injection and to determine the effect of different diets on BKD incidence.

Atlantic salmon postyearling parr (pyp) obtained from the Canadian Department of Fisheries and Oceans hatcheries were held in tanks supplied with surface water from Ingram Brook, Cape Breton. The temperature fluctuated from 0 to $17^{\circ} \mathrm{C}$ according to the season. Fish were administered vaccines during July and August when temperatures above $10^{\circ} \mathrm{C}$ would facilitate immune response.

The causative agent of BKD isolated from Atlantic salmon at Margaree Fish Culture Station, was grown on Evelyn's medium (KDM) (BULLOCK et al., 1974) or kidney disease medium $2\left(\mathrm{KDM}_{2}\right)$ (EVELYN. 1977) incubated at $15^{\circ} \mathrm{C}$. Cells were harvested and washed three times in $0.85 \%$ saline before further use. Cells were enumerated using a Petroff Hausser counting chamber.

For immunization, cells were either heated to $62^{\circ} \mathrm{C}$ for $45 \mathrm{~min}$ or formalin was added to a final concentration of $0.4 \%$ or both of these procedures were carried out. Prior to administration to fish, vaccine preparations were monitored for sterility on $\mathrm{KDM}$ or $\mathrm{KDM}_{2}$ media and in Fluid Thioglycollate Medium. Cellular antigens for use in agglutination tests were heated to $62^{\circ} \mathrm{C}$ for $45 \mathrm{~min}$ (Evelyn, 1971) prior to use.

Bacterins, administered by injection with Freund's complete adjuvant (FCA) contained inactivated BKD cell suspensions in $0.85 \%$ saline.

To evaluate the duration and level of immune response of small fish to BKD bacterins, underyearling parr (uyp) Atlantic salmon (weight 0.3 to $0.6 \mathrm{~g}$ ) were each injected ip with a volume of $0.025 \mathrm{~m} l$ containing $2.5 \times 10^{8} \mathrm{BKD}$ cells either in saline or emulsified in Freund's complete adjuvant saline. Fish vaccinated by immersion were also 
monitored. Individual blood samples were taken from 10 animals/treatment at about monthly intervals for 94 weeks after injection and the serum analyzed for agglutinating antibody titer (to a maximum of 40,960). External and intestinal mucus was also analyzed for BKD agglutinins. Protective immunity was determined from differences in relative incidence of natural BKD infections between vaccinated and control animals.

To determine the immune response to BKD antigens and the feasibility of conferring protective BKD immunity to pyp Atlantic salmon, fish (mean weight $=16$ or $20 \mathrm{~g}$ ) were injected intraperitoneally (ip) with a volume of $0.1 \mathrm{~m} l$ containing $1.2 \times 10^{\circ} \mathrm{BKD}$ cells either in saline or emulsified in FCA. Incidence of covert and overt BKD infections in live samples was utilized to assess the efficacy of the vaccination procedure in minimizing this disease or its effects. This experiment was repeated during three different years and the results are labelled Trial 1, 2 and 3.

The immune response of pyp Atlantic salmon was determined by analysis of serum, for BKD agglutinating antibodies. Sampling frequency was variable but approximated once per month. Blood taken from the caudal vein was processed and the agglutinating antibody titers of individual serum samples were determined using a microtiter apparatus (PATERSON and FrYer, 1974a, 1974b; PATERSON et al., 1980).

We utilized the annually occurring incidence of BKD at the Margaree Fish Culture Station (PATERSON et al., 1979) to assess the resistance or immunity conferred by these vaccination procedures. Mortalities and a live sample of fish were inspected for presence of symptomatic or overt BKD infections (indicated by presence of gross lesions on internal organs) and asymptomatic or covert infections demonstrated by the detection of BKD bacteria in kidney smears using the Indirect Fluorescent Antibody Technique (IFAT) (BULLOCK and STUCKEY, 1975).

Underyearling parr Atlantic salmon injected with BKD bacterins emulsified in Freund's complete adjuvant produced very high levels of specific agglutinins which persisted for up to 69 weeks after injection (Table 2). Unfortunately, no protection remained when required to combat the BKD epizootic some 90 weeks after injection.

Other means of antigen administration to under
Table 2. Antibody response of Atlantic salmon underyearling parr (Salmo salar) to a single intraperitoneal injection of killed Renibacterium salmoninarum cells emulsified in Freund's complete adjuvant

\begin{tabular}{clc}
\hline $\begin{array}{c}\text { Weeks after } \\
\text { treatment }\end{array}$ & Month & $\begin{array}{c}\text { Agglutinating } \\
\text { antibody titer } \\
\text { mean (range) }\end{array}$ \\
\hline 0 & Aug. 77 & $23(20-40)$ \\
3 & & $57(40-80)$ \\
5 & Sept. & $322(20-1280)$ \\
7 & & $4360(80-20480)$ \\
9 & Oct. & $804(150-5120)$ \\
11 & Nov. & $576(320-640)$ \\
13 & Nov. & $4704(80-20480)$ \\
20 & Jan. 78 & $4676(20-20480)$ \\
24 & Feb. & $8776(40-20480)$ \\
26 & Feb. & $6240(160-20480)$ \\
35 & Mar. & $326(20-1280)$ \\
47 & June & $330(<20-1280)$ \\
57 & Aug. & $330(20-1280)$ \\
69 & Nov. & $4322(<20-40960)$ \\
88 & April 79 & $16(<20-40)$ \\
94 & May & $32(<20-160)$ \\
\hline
\end{tabular}

yearling parr such as injection of cells in saline or immersion did not elevate BKD agglutinin levels significantly.

Since the BKD infections became severe in smolting Atlantic salmon, large live samples (50) were monitored for BKD monthly from April to June.

The immune response and protective immunity of postyearling salmon administered an injected vaccine with FCA were evaluated in trials carried

Table 3. Antibody response of Atlantic salmon post yearling parr (Salmo salar) to a single intraperitoneal injection of killed Renibacterium salmoninarum cells emulsified in Freund's complete adjuvant

\begin{tabular}{cccc}
\hline $\begin{array}{c}\text { Time after } \\
\text { injection } \\
\text { (week) }\end{array}$ & $\begin{array}{c}\text { Mean } \\
\text { agglutinating } \\
\text { antibody } \\
\text { titer } \\
(\mathrm{n}=10)^{*}\end{array}$ & $\begin{array}{c}\text { Range of } \\
\text { antibody } \\
\text { titers }\end{array}$ & $\begin{array}{c}\% \text { Antibody } \\
\text { response }\end{array}$ \\
\hline 0 & 20 & $20-40$ & 0 \\
12 & 575 & $160-10240$ & 75 \\
31 & 1374 & $40-10240$ & 90 \\
42 & 1664 & $160-20480$ & 65 \\
53 & 1412 & $20-10240$ & 70 \\
\hline
\end{tabular}

* Sample size. 
out in three different years. The BKD agglutinin response of Atlantic salmon pyp injected with killed BKD cells in adjuvant (Table 3 ) was significant. The high antibody titers observed for the majority of animals monitored for about one year after antigen injection indicated that these animals possessed a strong durable immune response to this antigen when administered with adjuvant.

The presence of BKD in these Atlantic salmon during the year following their transfer from a BKD free station to Margaree FCS and their vaccination treatment demonstrated the horizontal transmission of disease and subsequent increase in BKD infections as these fish smoltified.

Although no clear positive effect of the vaccine could be seen using IFAT for assessment, the incidence of BKD lesions or overt infection was reduced considerably by vaccination of pyp Atlantic salmon (yearlings) with a single injection of BKD cells emulsified in Freund's complete adjuvant (Fig. 5). This antigen administration reduced symptomatic BKD from $22 \%$ to $0 \%$ in Trial $1,29 \%$ to $3 \%$ in Trial 2 and $32 \%$ to $0 \%$ in Trial 3. The benefits of this reduction in view of the similar incidence of asymptomatic infections (using IFAT) in vaccinated and control groups must be carefully examined and assessed with other studies which should include return rates of adults for vaccinated and control fish.

The nutritional status of Atlantic salmon as a predisposing factor in the manifestation of $\mathrm{BKD}$
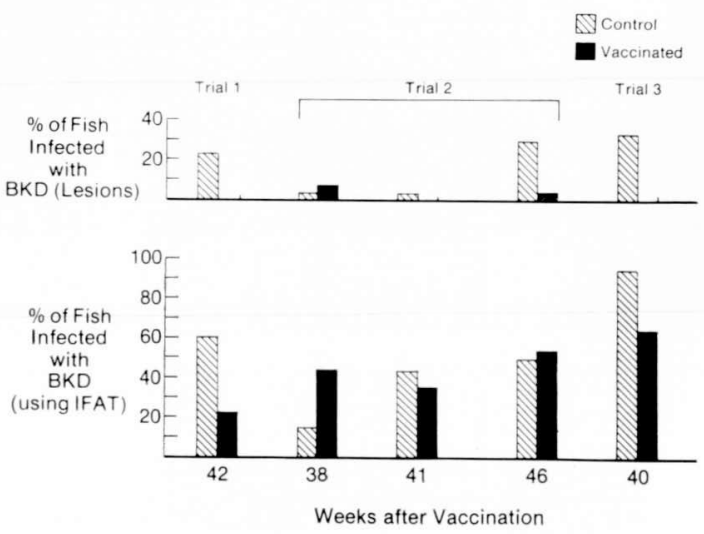

Fig. 5. Percent incidence of bacterial kidney disease (BKD) in post yearling Atlantic salmon following a single intraperitoneal injection of killed BKD cells emulsified in Freund's adjuvant. was studied under hatchery conditions. Smoltifying Atlantic salmon were monitored for BKD infections as well as changes in serum, kidney and liver during February, April and May. Serum samples were analysed for zinc, copper, iron, calcium, magnesium and phosphorus using an atomic adsorption spectrophotometer (Instrument laboratory, Model 751). Liver and kidney were examined for level of ascorbic acid [estimated using method of PoLK et al. (1960)] and vitamin A [determined according to method of AMEs et al. (1954)].

The mineral, vitamin and lipid analysis of serum kidney and liver from these Atlantic salmon smolts revealed that vitamin A, zinc and iron levels were significantly lower in BKD infected fish than in uninfected animals (Fig. 6). Serum calcium, phosphorus and magnesium levels in BKD infected animals were similar to values for uninfected fish.

In this experiment the commencement feeding in spring caused an increased deposition of ascorbic acid in the liver and kidney.

Kimura (1978) noted lower serum protein and hematocrit levels in samples taken from BKD infected fish. WeDEMEYer and Ross (1973) in a comparison of two diets in relation to KD incidence reported results which indicated some loss of renal function, depression of hematopoietic function, and some other nutrition effected responses to BKD infections.

To investigate the influence of nutrients on kidney disease, an 11 month feeding trial was designed and conducted. We attempted to deter-

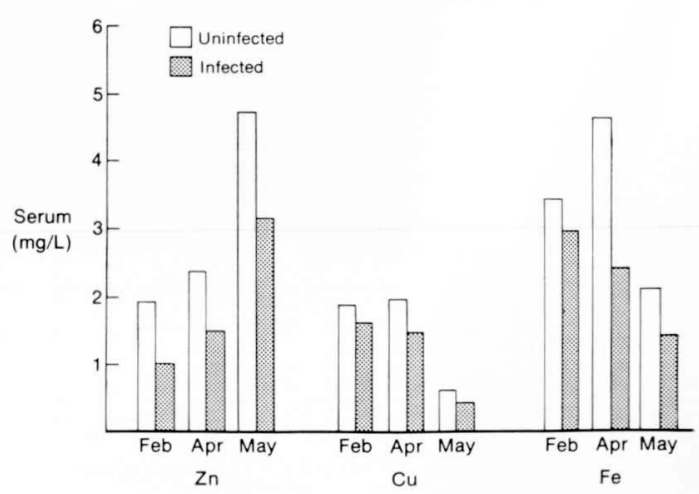

Fig. 6. Changes in serum zinc, copper and iron levels of Atlantic salmon infected with bacterial kidney disease. 
mine the effect of dietary minerals, vitamins and lipid supplements in relation to water quality and environment, in reducing the incidence of BKD infections. Margaree hatchery water is characterized by a high concentration of sodium, chloride and sulphate as well as a wide seasonal variation in calcium level due to the gypsum bed located near the water supply area. Seven different diets were fed to the post yearling Atlantic salmon.

The composition of the purified diet $(\mathrm{P})$ was as follows:

$\begin{array}{lc}\text { Vitamin free casein } & 41.3 \% \\ \text { Gelatin } & 13.0 \% \\ \text { Dextrin } & 20.0 \% \\ \text { Amino acid mixture } & 0.85 \% \\ \text { Vitamin mixture } & 2.7 \% \\ \text { Mineral mixture } & 5.1 \% \\ \text { Carboxy methyl cellulose } & 1.5 \% \\ \text { Alphacellulose } & 5.55 \% \\ \text { Herring oil } & 10.0 \%\end{array}$

The experimental diets were:

1. Commercial diet

2. Purified diet (P)

3. $\mathrm{P}+\mathrm{Zn}(130 \mathrm{mg} / \mathrm{kg})+\mathrm{Mg}(0.06 \%)$

4. $\mathrm{P}+$ high trace elements $(\mathrm{Fe}, \mathrm{Cu}, \mathrm{Mn}, \mathrm{Co}$, I \& F)

5. $\mathrm{P}+$ low calcium $(0.2 \%)$

6. $\mathrm{P}+$ high vitamin $\mathrm{A}, 15000 \mathrm{IU} / \mathrm{kg}$ and ascorbic acid $(0.3 \%)$

7. High nutrient density diet $(\mathbf{P}+15 \%$ lipid + high vitamins and trace elements) We utilized the Indirect Fluorescent Antibody
Technique (IFAT) and the presence of pustules on internal organs to diagnose BKD infections in various groups. Minimum levels of BKD infections were observed in fish fed high trace element or low calcium diets (Fig. 7) upon analysis of the July sample when elevated infections occurred. We attributed this therapeutic effect in reducing BKD infections to the increased availability of trace elements for dietary purposes. The reduction of serum zinc, iron and copper levels among BKD infected Atlantic salmon (Fig. 6) further supports the view that BKD infections influence trace element utilization. WOOdall and LAROCHE (1964) also demonstrated a therapeutic reduction of BKD infections by feeding chinook salmon a diet containing high levels of iodine $(10.1 \mu \mathrm{g} / \mathrm{g})$, a trace element.

The highest BKD infection incidence which occurred among fish fed the commercial diet can probably be attributed to a combination of factors including the high calcium content in commercial feeds ( 2 to $2.7 \%$ of diet) and the variable amounts of calcium in the hatchery water which may have increased the trace element requirements. Evidence has indicated that low concentrations of calcium are required (OGINO and TAKEDA, 1976; RaMSEY, 1977; LALL and Bishop, 1977). Experiments now in progress will attempt to further define the effect of individual trace elements on the incidence of BKD.

Increased interest in $\mathrm{BKD}$, and the application of modern techniques to study this disease have

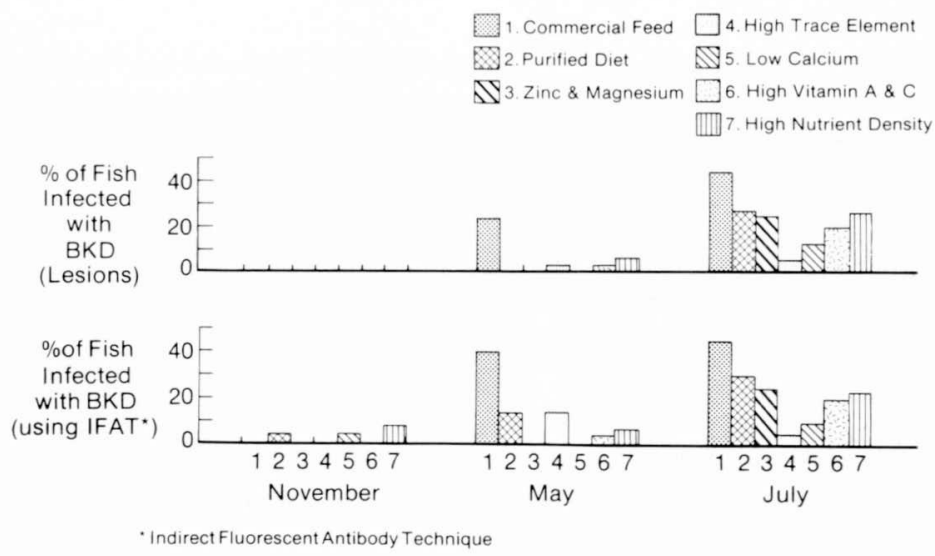

Fig. 7. Incidence of symptomatic (lesions) and asymptomatic (IFAT positive) bacterial kidney disease (BKD) infections in Atlantic salmon fed various experimental diets. 
recently made available much new information about both the disease and its recently named causative agent Renibacterium salmoninarum. This organism can now be cultured from infected animals with confidence. Diagnosis can now rely on rapid serological procedures which confirm the presence of the bacterium. We are getting to know more of the disease transmission methods, the organs affected, the infection modes, and the paradoxical situation in which we see the presence of so many infected animals without gross pathology.

Active work on prophylactic measures to minimize the effects of this disease now include vaccination, chemotherapeutics and nutrition as well as improvement of good management techniques, probably a key factor in controlling this disease.

\section{References}

Ames, A., H. A. Risley and P. L. Harris (1954): Simplified procedure for extraction and determination of vitamin A in liver. Anal. Chem., 26, 13781381.

Belding, D. L. and B. Merrill (1935): A preliminary report upon a hatchery disease of the Salmonidae. Trans. Am. Fish. Soc., 65, 76-87.

Bell, G. R. (1961): Two epidemics of apparent kidney disease in cultured pink salmon (Oncorhynchus gorbuscha). J. Fish. Res. Board Can., 18, 559-562.

Bullock, G. L., H. M. STuCKey and P. K. CHeN (1974): Corynebacterial kidney disease of salmonids: growth and serological studies on the causative bacterium. Appl. Microbiol., 28, 811-814.

Bullock, G. L. and H. M. Sruckey (1975): Fluorescent antibody identification and detection of the Corynebacterium causing kidney disease of salmonids. J. Fish. Res. Board Can., 32, 2224-2227.

Bullock, G. L., B. R. Griffin, and H. B. STuckey (1980): Detection of Corynebacterium salmoninus by direct fluorescent antibody test. Can. J. Fish. Aquat. Sci., 37, 719-721.

Chen, P. K., G. L. Bullock, H. M. Stuckey, and A. C. Bullock (1974): Serological diagnosis of cornybacterial kidney disease of salmonids. $J$. Fish. Res. Board Can., 31 (12), 1939-1940.

Coulson, J. J. (1977): Studies on bacterial kidney disease in salmonids. M. Sc. thesis, University of Guelph, Guelph, Ontario, Canada.

Earp, B. J., C. H. Ellis, and E. J. Ordal (1953): Kidney disease in young salmon. Wash. Dept. Fish. Spec. Rept. Series No. 1.
Ellis, R. W., A. H. Novotny, and L. W. Harrell (1978): Case report of kidney disease in a wild chinook salmon, Oncorhynchus tschawytscha, in the sea. J. Wildl. Dis., 14, 120-123.

EVELYN, T.P.T. (1971): The agglutinin response in sockey salmon vaccinated intraperitoneally with a heat killed preparation of the bacterium responsible for salmonid kidney disease. J. Wildlife Dis., 7, 328-335.

Evelyn, T.P.T., G. E. Hoskins, and G. R. Bell (1973): First record of bacterial kidney disease in an apparently wild salmonid in British Columbia. $J$. Fish. Res. Board Can., 30, 1578-1580.

EVELYN, T. P. T. (1977): An improved growth medium for the kidney disease bacterium and some notes on using the medium. Bull. Off. Int. Epizoot., 87(5-6), 511-513.

Frantsi, C., T. C. Flewelling, and K. G. Tidswell (1975): Investigations on Corynebacterial kidney disease and Diplostomulum sp. (eye fluke) at Margaree Hatchery, 1972-73. Environment Canada, Fisheries and Marine Service, Resource Development Branch, Maritimes Region, Technical Report Series - MAR/ T-75-9.

Frantsi, C., J. A. Ritter, and P. F. Elson (1977): Effect of Corynebacterial kidney disease on ocean survival and return of Atlantic salmon (Salmo salar) ICES CM 1977/M: 29.

Kawamura, H., T. Awakura, K. Watanabe, and $\mathrm{H}$. Matsumoto (1978): Therapeutic effects of Erythromycin and the sensitivity of four salmonid fishes to bacterial kidney disease. Sci. Rep. Hokkaido Salmon Hatchery, 32, 21-35.

Kimura, T. (1978): Bacterial kidney disease of salmonids. Fish Pathology, 13, 43-52.

Kimura, T., Y. Ezura, K. Tajima, and M. Yoshimizu (1978): Serological diagnosis of bacterial kidney disease (BKD); immunodiffusion test by heat stable antigen extracted from infected kidney. Fish Pathol., 13 (2), 103-108.

LAIDLER, L. A. (1980): Detection and identification of bacterial kidney disease (BKD) organism by the indirect fluorescent antibody technique. J. Fish Dis., 3, 67-69.

LALl, S. P. and F. J. Bishop (1977): Studies on mineral and protein utilization by Atlantic salmon (Salmo salar) grown in sea water. Canadian Fisheries and Marine Service, Res. Dev. Tech. Report. $\$ 688$. $16 \mathrm{p}$.

OgINo, C. and H. TAKEDA (1976): Mineral requirements in fish. III. Calcium and phosphorous requirements in carp. Bull. Japan. Soc. Sci. Fish., 42, 793-800.

Ordal, E. J. and B. J. EARP (1956): Cultivation and 
transmission of the etiological agent of kidney disease in salmonid fish. Proc. Soc. Exp. Biol. Med., 92, $85-88$.

Paterson, W. D. and J. L. Fryer (1974a): Effect of temperature and antigen dose on the antibody response of juvenile coho salmon (Oncorhynchus kisutch) to Aeromonas salmonicida endotoxin. $J$. Fish Res. Board Can., 31, 1743-1749.

Paterson, W. D. and J. L. Fryer (1974b): Immune response of juvenile coho salmon (Oncorhynchus kisutch) to Aeromonas salmonicida cells administered intraperitoneally in Freund's complete adjuvant. $J$. Fish. Res. Board Can., 31, 1751-1755.

Paterson, W. D., C. Gallant, D. Desautels, and L. Marshall (1979): Detection of bacterial kidney disease in wild salmonids in the Margaree River System, and adjacent waters using an indirect fluorescent antibody technique. J. Fish Res. Board Can. 36, 1464-1468.

Paterson, W. D., D. Desautels and J. Weber (1980): The immune response of Atlantic salmon (Salmo salar) to the causative agent of bacterial kidney disease (Renibacterium salmoninarum). J. Fish Dis. 4, 99-111.

Pippy, J.H.C. (1969): Kidney disease in juvenile Atlantic salmon (Salmo salar) in the Margaree River. J. Fish Res. Board Can., 26, 2535-2537.

Polk, A., T. Flangan, and E. J. Van Loon (1960): Rapid method for determination of ascorbic acid in urine. Clin. Chem., 6: 558-563.

Ramsay, G. L. (1977): Fish Nutrition. Recent Ad- vances. Proc. Internat. Sympos. Cult. Salmonids. Seattle, Washington. Arpil 1, 1977.

SANDers, J. E., K. S. Pilcher, and J. L. Fryer (1978): Relation of water temperature to bacterial kidney disease in choho salmon (Oncorhynchus kisutch) sockeye salmon ( $O$. nerka), and steelhead trout (Salmo gairdneri).

SANDERs, J. E. and J. L. Fryer (1980): Renibacterium salmoninarum gen. nov., the causative agent of bacterial kidney disease in salmonid fishes. Int. J. Syst. Bacteriol., 30, 496-502.

Smith, I. W. (1964): The occurrence and pathology of Dee Disease. Freshwater Salmon Fish Res., 34, $1-12$.

Wedemeyer, G. A. and A. J. Ross (1973): Nutritional factors in the biochemical pathology of corynebacterial kidney disease in the coho salmon (Oncorhynchus kisutch). J. Fish. Res. Board Can., 30, 296-298.

Wood, E. M. and T. YAsutake (1956): Histopathology of kidney disease in fish. Am. J. Pathol., 32, 845-857.

Wood, J. W. and J. WALlis (1955): Kidney disease in adult chinook salmon and its transmission by feeding to young chinook salmon. Fish. Comm. Oregon, Research Brief, 6, 32-40.

WoOdall, A. N. and G. Laroche (1964): Nutrition of salmonid Fishes. XI. Iodide requirements of Chinook salmon. J. Nutrition, 824, 475-482.

Yамамото, T. (1975): Infectious pancreatic necrosis virus and bacterial kidney disease appearing concurrently in populations of Salmo gairdneri and Salvelinus fontinalis. J. Fish. Res. Board Can., 32, 92-95. 